\title{
Identity as a Means of Recruitment for Political Parties and the Influence of Leaders in Sigi Regency, Central Sulawesi Province
}

\author{
Darwis $^{1}$, Sasterio $^{1}$ \\ *Corresonding Email: darwisuntad@gmail.com \\ ${ }^{1}$ Government Science Study Program, Faculty of Social and Political Sciences, Tadulako \\ University, Palu, Indonesia
}

\begin{abstract}
This article explains how the means of recruiting political parties in finding candidates for regional head in Sigi Regency. And how role models can influence the way people think in choosing. This study uses a qualitative method, by collecting data in the form of statements, behaviors and events through the use of observation methods, in-depth interviews, focus discussion groups, and searching for complementary materials from document data obtained to be analyzed as a relevant unit of information based on this research study. The results showed that even though the candidates were nominated by political partie the election 2015 in Sigi Regency, the candidates still represented their communities based on their religious identity. Each candidate for regional head who does not meet the qualifications or does not pass the administrative selection at the General Election Commissions of Sigi Regency each has a distinctive feature, namely a religious identity. The people of Sigi Regency seem to be more interested in the figures who will run for themselves than the political parties that carry them.
\end{abstract}

Keywords: Pragmatism, Figures, Political Parties, Regional Heads, Regional Elections

Received: April 1, 2021

Revised: April 28, 2021

Accepted: May 14, 2021

\section{Introduction}

Political parties are one of the foundations of a democratic political system (Hariyanti et al., 2018). The political recruitment process in general in various countries can be done through participants, namely being strong supporters and loyal to the party, compartmentalization, namely recruitment based on an educational background, immediate survival, namely recruitment determined by party elites without taking into account the ability of the person being recruited, and civil service reform, namely recruitment. because on the basis of service (Ardiansya, 2018). However, the primary motivation for political parties to attract and elect candidates is to increase their party's vote share. This candidacy process takes place within the party and has an effect on the subsequent stages, including the voter election of candidates and the voter selection stage (Amalia, 2018). When members of identified political parties or leaders are threatened with failure, we agree that many of them would be motivated to double their vote and even convince others to join their political group (Van Bavel \& Pereira, 2018). What must be remembered is that the party's commitment to democracy is not unjustified (Nurdin, 2019).

In Indonesia, the pluralistic nature of society is an obstacle in and of itself for democratic practices (Mouliza Kristhopher \& Chusnul, 2017). Each party and candidate has its own portrait in the setting in which he travels. This term refers to the public's or voters' opinion of a party or candidate at a certain point in time (Susilastuti, 2018). To determine whether or not

Copyright (C) 2021, International Journal Papier Public Review, Under the license CC BY-SA 4.0 DOI: https://doi.org/10.47667/ijppr.v2i2.86 
other networks exist, as well as their potential value (Bertrand et al., 2020). However, perceptions of the system's openness to individual political activity are involved (Halpern et al., 2017).

The regime for direct regional head elections that involves the political community electing local leaders is a political product of the reform era since its inception 18 years ago. This direct election of regional heads is an implementation of the decentralization policy which provides political authority to regions, both provinces and districts and cities in producing the top executive leadership as head of regional government. The decentralization policy provides political opportunities for citizens to make choices and to be elected to lead their regions. The wider information that the public receives about political figures, from personal information to the track records of political figures, makes people unconsciously identify these political figures, starting from the physical, character, personality and track record of the political figure (politician) (Andriyani et al., 2017). They are crucial to research in order to comprehend how leaders deal with various audiences (Lalancette \& Raynauld, 2019).

Public advertising for the President / Vice President, Governor / Deputy Governor, Mayor / Deputy Mayor, Regent / Deputy Regent, and other political events are common in the months leading up to the general election (Anshori, 2018). Religion-based parties do not necessarily form coalitions with religion-based parties, and depending on the current coalition, even political parties with opposing views can join the same coalition. This is because political parties engaging in elections are attempting to draw not only one kind of electorate, but as many as possible (Ekowati, 2019). The regional government's changing form is often determined by the party system (Hinnebusch, 2017).

Since being an autonomous region of its own, Sigi Regency is separated from Donggala Regency, it has carried out a succession of leadership for regional heads who have been directly elected by the people of Sigi Regency. But without roots (habitat), political parties recruited regional head candidates in the direct regional head elections on December 92015 , where many of the nation's children in villages and sub-districts morally and educationally follow categorization to be pushed by political parties. Meanwhile, the ability to nominate themselves (individual candidates) must be accompanied by the need for the required Identity card, which must then be checked administratively and factually. It is in this context that the public mindset generally assesses that local political events in the people's democratic party in Sigi Regency have been infected with the "pragmatism" virus. Therefore, with this social reality, the researchers conducted a deeper study of identity as a means of recruiting political parties and the influence of figures in Sigi district, Central Sulawesi province.

\section{Methods}

There are no political parties in Indonesia that were formed through a bottom-up process. Several elites formed the party, which was then followed by party organization at a lower level. As a result, political parties are elitist. Even though political parties have structured decisionmaking structures, policy is normally decided by elites or main players within them. This elitist style has the potential to undermine democratic party structures (Purwaningsih \& Singka Subekti, 2017). The biggest problem for political parties in Indonesia today is to handle the appointment and placing of cadres in political roles and party cadres who have not been fully enforced, as well as the centralization of all political party operations and decisions in the central council (Amin et al., 2018). In Sigi Regency, this study focuses on the recruiting of regional head candidates and the impact of role models.

Copyright (C) 2021, International Journal Papier Public Review, Under the license CC BY-SA 4.0 DOI: https://doi.org/10.47667/ijppr.v2i2.86 
This study employs a comparative case study methodology (Sá \& Sabzalieva, 2018), where findings are made on large or small populations specifically, but data is collected by sampling the population (Ibrahim \& Madjid, 2018). A qualitative descriptive approach was used (Daswati et al., 2019), the aim of empirical data is to spark new concepts for cross- platform comparative research that will gradually improve our understanding of contemporary political campaigns (Bossetta, 2018). Techniques for gathering data include observation, reporting, interviews, and group meetings (Ahsan et al., 2020). The final move is to draw conclusions based on the findings of the study (Sukino et al., 2019). More research is required to assess the external validity of our findings (Bail et al., 2018).

\section{Results and Discussion}

The law on the election of regional heads of governors and deputy governors, regents and deputy regents, mayors and deputy mayors states that every citizen who meets the requirements to run for regional head, the nomination process must go through political party political recruitment. This means that each candidate for regional head must be promoted by political parties and coalitions of political parties by meeting the threshold of $20 \%$ of the number of seats in the House of Representatives and $25 \%$ of the number of voters in the region. Likewise, independent candidates (individuals) can collect the number of photocopies of identity cards.

The political recruitment process of political parties for candidates who will be brought up to the stage of the regional head election process does not directly stipulate that the candidates to be nominated must come from political parties or political party cadres. This is because the pattern of recruitment of political parties for every citizen who meets the requirements to be proposed as a candidate for regional head is so loose. So that many local people have the same opportunity to appear as regional heads. This shows that there is actually no chance of a local political oligarchy. Local political oligarchy is only dominated by political elites who come from political parties and House of Representatives . In fact, many figures who deserve to appear come from villages and sub-districts who should have received political opportunities in the process of nominating regional heads in Sigi Regency.

Political parties recruit candidates for regional heads in direct regional head elections simultaneously on December 9, 2015 without root (habitat), where many of the nation's children in villages and sub-districts morally and educatively meet the categorization to be promoted by political parties. Meanwhile, the opportunity to nominate themselves (independent candidates) must be faced with the requirement to collect the number of ID cards required to vote which are then verified administratively and factually. In the process of direct regional head elections in Sigi Regency, there was only one independent candidate, namely Ir. Suarman Lakantja SEPE, M.Si and Andi Lasipi, SIP. Then at the administrative and factual verification stages they cannot continue to the next stage.

Many factors lead to cultural fading and the strengthening of pragmatism, including weak structures and low party control, high campaign costs, money politics, low voter party identification, and the strengthening of populism in the media and among voters (Makhasin, 2016). Political parties recruiting candidates for regional head of Sigi Regency in the regent and deputy regent (regional head) election regime of Sigi Regency in 2015 are more pragmatic in nature, namely recruiting candidates not based on the morality and integrity approach, but rather on popularity and having financial capabilities. With the political nature of pragmatism in recruiting candidates for regional heads, the regent and deputy regent only circulate at the level of the party elite oligarchy and the local bureaucracy alone. The pragmatism of political

Copyright (C) 2021, International Journal Papier Public Review, Under the license CC BY-SA 4.0 DOI: https://doi.org/10.47667/ijppr.v2i2.86 
parties can also hamper the birth of regional head candidates who come from the grass root community.

Sales and support procurement, where merging or terminating a deal to support a candidate is always decided pragmatically, in this case the amount of money is negotiated, is usually what happens (Noor, 2014). Because there are issues that running through a political party must have adequate financial strength with provisions for "political dowry". This is evidenced by the approaching regional head elections, political parties are starting to get busy and seek access to the Jakarta DPP to get information about the number of political dowries that candidates have to pay to political parties. With this political dowry that erodes the birth of regional heads who are less qualified and have no mandate. The quality of skills should be described as fulfilling the main needs and objectives in terms of labor, procedures and tasks, as well as the environment (Sadia et al., 2019). Likewise, becoming a public official who has low idealism and integrity in developing regions and eradicating corruption, collusion and nepotism (CCN). Therefore, in order to produce quality regional heads with good integrity, political parties should avoid the aroma of money politics in the form of political dowries and irresponsible contributions.

Recruitment of candidates for regional heads in Sigi Regency, political parties should conduct recruitment that is a multi-level convention, starting from the village, sub-district to the city / regency level. Thus, the candidates who will be nominated are the results of the aspirations of the people who already have a level of electability, popularity and public preference. Political parties do not need to charge registration fees until the nomination stage through political parties. The bearer political party only charges the administrative costs of the regional head election process to candidates who have been mutually agreed with the people who entrust them to fight on the day of the regional head election. In reality, the political practice in the regional head elections in Sigi Regency in 2015, even though the candidates were promoted by political parties, the candidates still represented their communities based on their religious identity. In general, both candidates who were not accommodated in the qualifications as candidates for regional head and who failed the administrative selection at the general election commission of Sigi Regency each carried their special characteristics, namely Islamic religious identity and Christian identity. The religious polarization of candidates is a political decision made by political parties and groups in order to win the election for Regent and Deputy Regent of Sigi Regency for the term 2016-2021. This demonstrates how religion's boomerang effect can influence a candidate's popularity (Swire et al., 2017).

Based on the Direct Regional Head Election Law No.8 of 2015, every figure who wishes to advance in the direct regional head election must get a bearing party and an independent candidate (individual candidate). Even though political parties are the means of political vehicles, they are not the only determining factor in getting the most votes in winning these local political battles. However, what is more decisive is the factor of regional head candidate figures who are promoted by political parties. Therefore, political parties recruit through a candidate selection process by setting criteria based on the reality of the social character of the people of Sigi Regency. Sigi Regency which has heterogeneous character patterns and patterns of society, namely the population comes from various ethnicities and religions. Even though they are ethnically diverse, the more striking patterns and patterns of society are the differences between the two religious communities that are predominantly Muslim and Protestant Christians. In this context, the religious dimension factor becomes a political preference for political parties in recruiting figures to be nominated in the process of simultaneous direct

Copyright $($ C 2021, International Journal Papier Public Review, Under the license CC BY-SA 4.0 DOI: https://doi.org/10.47667/ijppr.v2i2.86 
regional head elections in Sigi Regency in 2015. Political parties as a means of political vehicles in recruiting regional head candidates, of course what is more important is the factor of the level of electability of the figures who are going to be sold to the community (political marketing).

People naturally avoid politics because of the sometimes harsh and violent aspects of the political system (Febriantanto, 2019). The condition of the image of political parties which is increasingly degraded due to the actions of political party elites both at the national and regional levels which are often caught and caught by the law that is watched by the public in regions (villages and sub-districts) throughout the archipelago, including in Sigi Regency and can influence voter behavior. The people in Sigi Regency don't seem to care about the political party that supports them, but rather on the prominent figures who will become candidates. Several factors are the reasons why people make choices about figures, namely first, the factor of personality relationships between figures and society. The community and the figures that will be shown have the same bonds of religious identity, family intimacy, friendship of friends (friendship). This support factor comes from various ethnicities and religions. Second, the existence of a similarity in religious beliefs as a factor in the natural relationship between figures and their supporters. Religious belief in the regional head elections in Sigi Regency in 2015 is more prominent than ethnic identity. Thus, community support for one figure comes from various ethnicities. For example, from Toraja ethnicity, Kaili Daa ethnicity, Bugis ethnicity, Javanese ethnicity, and Kaili ethnicity. Third, the factor of financial strength, this factor then becomes the support for the success team to conduct mass support. This is because sociologically that society in general should provide support should get benefits. Therefore, figures with financial strength have the opportunity to advance in the next stage of the regional head election process. The political reality in the process of direct regional head elections in Sigi Regency in 2015 is that the figures who appear in the regional head elections can be categorized as local elites who have the potential for sufficient financial power as a political machine.

Indicators that these figures as local elites come from the regional government bureaucracy in echelon II A and politicians who are members of the DPRD in Sigi Regency. Candidates for the Regent and Deputy Regent of Sigi in the 2015 regional head election who came from the bureaucracy in occupying echelon II strategic positions (Head of Service) were Moh. Irwan Lapatta, S.Sos, M.Si, former Head of Donggala District Civil Service, Nurzain Djaelangkaran, SH former Head of the Sigi Regency Bappeda, H. Husen Habibu, M.Hi and Drs.Pasaua, MM former Sekab and Head of the Sigi Regency Office, Moh.Agus Rahmat, SP, MES former Head of the Agriculture Office, Wardha the former school principal. Meanwhile, those who came from politicians were Paulina, SE, M.Si, former Deputy Chairman of the DPRD Sigi Regency, Ajub Willem Darawia, ST, MT, a former member of the DPRD of Central Sulawesi Province. This shows that in addition to the bonds of religious identity as a cultural capital that unites various ethnicities, it is the factor of financial strength and social class status that become "political machines".

The inclusion of jop-hopper politicians, celebrity cadres, wealthy individuals, and businesspeople poses public questions about political parties' ability to carry out political regeneration on a pragmatic level. As a result, political parties are widely regarded as struggling to include education and political rehabilitation as part of their political recruiting feature (Sugiarto \& Yuwanto, 2020). The community provides support based on the motivation to get benefits in the form of basic food assistance, social donations, transportation money, gas money

Copyright (C) 2021, International Journal Papier Public Review, Under the license CC BY-SA 4.0 DOI: https://doi.org/10.47667/ijppr.v2i2.86 
and others. This mindset is then manipulated by the success team to build sympathy for the public to make their choice on the promoted candidate. They are now used as tools for politics and propaganda, with carefully staged photos, canned but well-crafted responses to other users, and political ends (Howard et al., 2018). The most controversial question is how this transformation took place (Reale et al., 2018).

\section{Conclusion}

Direct regional head elections with the participation of the public to participate in politics to vote are representative politics. Theoretically, it is in voter behavior that people vote based on solidarity relations between religions, ethnicities, cultures, and regional origins. Therefore, the pair of candidates for the Regional Head of Sigi Regency in the 2015 general election for the regional head election is an objective condition of the various characteristics and patterns of society. This political reality, constitutionally provides equal rights and obligations to every citizen to gain access to the positions of Regent and Deputy Regent and as well as strategic positions in the Regional Government Bureaucracy in Sigi Regency. The most important thing to know is that the pragmatism of the people in selecting candidates for regional head can erode the quality of local democracy in Indonesia. In fact, the condition of the political system has conducted several direct elections in electing public officials. The public should not choose based solely on financial gain or desire the project package as a "political service", but choose based on the candidate's morality and integrity approach. In such a context, the consolidation of democracy at the local level is relatively far from the hope of producing trustworthy leaders and protecting all levels of society.

\section{References}

Ahsan, S. C., Samad, M. A., Zuada, L. H., \& . N. (2020). Implementation of E-Government Policies: Case Study of Goods and Services Procurement in Buol Regency, Central Sulawesi, Indonesia. Saudi Journal of Economics and Finance, 4(6), 276-280. https://doi.org/10.36348/sjef.2020.v04i06.013

Amalia, L. S. (2018). Recruitment System for Women's Legislative Candidates in PKSaPKB in Indonesia. Advances in Social Science, Education and Humanities Research (ASSEHR), 141(ICOPOSDev 2017), 205-208. https://doi.org/10.2991/icoposdev17.2018.43

Amin, M., Warjio, D., \& Kusmanto, H. (2018). Recruitment, Certification And Financial Management Of Political Party In The Province Of North Sumatera, Indonesia. Advances in Social Science, Education and Humanities Research, 136(Icosop 2017), 640-655. https://doi.org/10.2991/icosop-17.2018.97

Andriyani, T., Zahra, S., \& Swasti, D. D. (2017). Gambaran Pola Identifikasi Generasi Milenial Dalam Memilih Tokoh Politik Melalui Media Sosial. Jurnal Ilmiah Penelitian Psikologi: Kajian Empiris \& Non-Empiris, 3(2), 69-81. https://doi.org/10.22236/JIPP- 39

Anshori, A. (2018). Pengaruh Iklan Politik Terhadap Persepsi Pemilih Kota Medan Tahun 2018. Jurnal Interaksi, 2(2), 132-144. https://doi.org/10.30596/ji.v2i2.2091

Ardiansya, A. (2018). The Political Recruitment of Prosperous Justice Party (PKS) in Takalar 
Election 2017. Jurnal Ilmiah Ilmu Administrasi Publik, 8(2), 147. https://doi.org/10.26858/jiap.v8i2.8112

Bail, C. A., Argyle, L. P., Brown, T. W., Bumpus, J. P., Chen, H., Fallin Hunzaker, M. B., Lee, J., Mann, M., Merhout, F., \& Volfovsky, A. (2018). Exposure to opposing views on social media can increase political polarization. Proceedings of the National Academy of Sciences of the United States of America, 115(37), 9216-9221. https://doi.org/10.1073/pnas.1804840115

Bertrand, M., Bombardini, M., Fisman, R., \& Trebbi, F. (2020). Tax-exempt lobbying: Corporate philanthropy as a tool for political influence. American Economic Review, 110(7), 2065-2102. https://doi.org/10.1257/aer.20180615

Bossetta, M. (2018). The Digital Architectures of Social Media: Comparing Political Campaigning on Facebook, Twitter, Instagram, and Snapchat in the 2016 U.S. Election. Journalism and Mass Communication Quarterly, 95(2), 471-496. https://doi.org/10.1177/1077699018763307

Daswati, D., Samad, M. A., \& Wekke, I. S. (2019). Collaborative Governance Dalam Pengelolaan Integrated Community Shelter Pasca Bencana Di Kota Palu Collaborative Governance in the management of Integrated Community Shelters post disaster ( ICS ) in the City of Palu. Politik Indonesia: Indonesian Political Science Review, 5(2), 229- 242.

Ekowati, E. Y. (2019). Pragmatisme Politik: Antara Koalisi, Pencalonan dan Calon Tunggal dalam Pilkada (E ndah Yuli Ekowati) Pragmatisme Politik: Antara Koalisi, Pencalonan, dan Calon Tunggal Dalam Pilkada. Jurnal Transformative, 5(1), 16-37. https://doi.org/10.21776/ub.transformative.2019.005.01.2

Febriantanto, P. (2019). Analisis Faktor Determinan Peningkatan Partisipasi Politik Penyandang Disabilitas pada Pilkada Kota Yogyakarta 2017. Jurnal PolGov, 1(1), 157. https://doi.org/10.22146/polgov.v1i1.48859

Halpern, D., Valenzuela, S., \& Katz, J. E. (2017). We Face, I Tweet: How Different Social Media Influence Political Participation through Collective and Internal Efficacy. Journal of Computer-Mediated Communication, 22(6), 320-336. https://doi.org/10.1111/jcc4.12198

Hariyanti, H., Darmawan, C., \& Masyitoh, I. S. (2018). The Role of Political Parties in Building Loyalty Women Cadres through Political Education. Advances in Social Science, Education and Humanities Research, 251(2), 548-552. https://doi.org/10.2991/acec-18.2018.123

Hinnebusch, R. A. (2017). Political parties in MENA: Their functions and development. British Journal of Middle Eastern Studies, 44(2), 159-175. https://doi.org/10.1080/13530194.2017.1281577

Howard, P. N., Woolley, S., \& Calo, R. (2018). Algorithms, bots, and political communication in the US 2016 election: The challenge of automated political communication for election law and administration. Journal of Information Technology and Politics, 15(2), 81-93. https://doi.org/10.1080/19331681.2018.1448735 
Ibrahim, A. H. H., \& Madjid, S. (2018). The role of political parties on election commission performance in 2015 mayor election of Ternate city. International Journal of Scientific and Technology Research, 7(2), 118-123. https://doi.org/10.5281/zenodo.4326704

Lalancette, M., \& Raynauld, V. (2019). The Power of Political Image: Justin Trudeau, Instagram, and Celebrity Politics. American Behavioral Scientist, 63(7), 888-924. https://doi.org/10.1177/0002764217744838

Makhasin, L. (2016). Orientasi Ideologi dan Pragmatisme Politik Model Pembentukan Koalisi dalam Pilkada Serentak di Jawa Tengah 2015. Jurnal Ilmu Sosial Dan Ilmu Politik, 19(3), 234. https://doi.org/10.22146/jsp.15685

Mouliza Kristhopher, M. K., \& Chusnul, C. (2017). Political Recruitment of ChineseIndonesian Women Candidate: Study of Pdi Perjuangan'S Recruitment in Semarang City Legislative Election 2014. PEOPLE: International Journal of Social Sciences, 3(2), 1156-1174. https://doi.org/10.20319/pijss.2017.32.11561174

Noor, F. (2014). Perilaku Politik Pragmatis Dalam Kehidupan Politik Kontemporer: Kajian Atas Menyurutnya Peran Ideologi Politik. Masyarakat Indonesia, 40(1), 57-74. https://doi.org/10.14203/jmi.v40i1.106

Nurdin, A. A. (2019). Islam supports democracy: The views of partai Islam SE-Malaysia (PAS) and their implementation in the recruitment of the party's members and leaders. Qudus International Journal of Islamic Studies, 7(1), 101-128. https://doi.org/10.21043/qijis.v7i1.4809

Purwaningsih, T., \& Singka Subekti, V. (2017). Political Family and Intra-Party Democracy in Indonesia. (A Study on the Political Recruitment of the Golkar Party during the Reform Era in South Sulawesi). Journal of Government and Politics, 8(1). https://doi.org/10.18196/jgp.8154

Reale, E., Avramov, D., Canhial, K., Donovan, C., Flecha, R., Holm, P., Larkin, C., Lepori, B., Mosoni-Fried, J., Oliver, E., Primeri, E., Puigvert, L., Scharnhorst, A., Schubert, A., Soler, M., Soòs, S., Sordé, T., Travis, C., \& Van Horik, R. (2018). A review of literature on evaluating the scientific, social and political impact of social sciences and humanities research. Research Evaluation, 27(4), 298-308. https://doi.org/10.1093/reseval/rvx025

Sá, C. M., \& Sabzalieva, E. (2018). The politics of the great brain race: public policy and international student recruitment in Australia, Canada, England and the USA. Higher Education, 75(2), 231-253. https://doi.org/10.1007/s10734-017-0133-1

Sadia, H., Mustari, N., St. Nurmaeta, \& Razak, F. S. H. (2019). Strategi Pemerintah Dalam Pengembangan Kapasitas Program Pendidikan Gratis Di Kabupaten Bone. Journal of Public Administration and Government, 1(1), 39-45. https://doi.org/10.22487/jpag.v1i1.16

Sugiarto, M. D., \& Yuwanto, Y. (2020). Celebrities in the Recruitment of Candidates for Legislative Members of the Indonesian Parliament in the Legislative Elections. Jurnal Ilmu Sosial, 19(2), 117-136. https://doi.org/10.14710/jis.19.2.2020.117-136 
Sukino, W. G., Samad, M. A., Mangngasing, N., \& Rivai, A. (2019). Manajemen Mitigasi Bencana Kota Palu Palu City Disaster Mitigation Management. Journal of Public Administration and Government, 1(2), 1-8.

Susilastuti. (2018). Marketing Politik DPP Partai Gerindra Pada Pemilu Legislatif 2014. Jurnal Ilmu Sosial Dan Politik, 4(2), 221-242. https://doi.org/10.14710/politika.9.1.2018.60-70

Swire, B., Berinsky, A. J., Lewandowsky, S., \& Ecker, U. K. H. (2017). Processing political misinformation: Comprehending the trump phenomenon. Royal Society Open Science, 4(3). https://doi.org/10.1098/rsos.160802

Van Bavel, J. J., \& Pereira, A. (2018). The Partisan Brain: An Identity-Based Model of Political Belief. Trends in Cognitive Sciences, 22(3), 213-224. https://doi.org/10.1016/j.tics.2018.01.004 